\title{
A comparison of the rates of success and complications in the application of central venous catheters applied with ultrasonography or the landmark method
}

\section{Ultrasonografi eșliğinde veya landmark yöntemiyle uygulanan, santral venöz kateter uygulamalarındaki başarı oranları ve oluşan komplikasyonların karşıllaştırılması}

\author{
Hakan Akelma1 ${ }^{\mathbb{D}}$, Fikret Salık ${ }^{\mathbb{D}}$, Cem Kıvılcım Kaçar1 ${ }^{\mathbb{D}}$, Osman Uzundere1 ${ }^{(\mathbb{D})}$, Ebru Tarıkçı Kıııç2 \\ 1 Health Sciences University Gazi Yaşargil Education and Research Hospital Department of Anesthesiology and Reanimation, \\ Diyarbakır \\ 2 Ümraniye Education and Research Hospital Department of Anesthesiology and Reanimation, Istanbul
}

\section{Abstract}

Background: To compare the rates of success and the complications that can develop during the central venous catheterizations with ultrasonography and Landmark methods, usually used in the intensive care unit.

Methods: This study was conducted retrospectively by scanning the files of 100 patients. Patients were divided into two groups as Ultrasonography $(n=49)$ and Landmark $(n=51)$. The distribution of the catheter diameters with the information obtained from the files based on groups, from which artery the operation was made based on the groups, the distribution of gender based on the groups, and the complications that occurred were compared.

Results: In our study, the distribution of the thickness of the catheters used for CVCs did not vary by group, there was no variation in terms of gender distribution in the groups, the CVC was not entered with the USG method, 1 multiple-operation was tried in the IJV catheterization with the USG method, and no other complications were experienced.

Conclusions: USG method is a reliable, practical, and applicable method in ICU for CVC (excepted SCV(subclavian vein) ) application.

Keywords: Central venous catheterization, Landmark method, Ultrasonography

Öz.

Amaç: Genellikle yoğun bakımda kullanılan USG (ultrasonografi) ve Landmark yöntemleri ile santral venöz kateterizasyonlarda ortaya çıkabilecek başarı oranlarını ve komplikasyonları karşılaştırmaktır. Materyal ve Metot: Bu çalışma geriye dönük olarak 100 hastanın dosyasını tarayarak gerçekleştirildi. Hastalar Ultrasonografi $(n=49)$ ve Landmark $(n=51)$ olmak üzere iki gruba ayrıldı. Dosyalardan elde edilen bilgilerle kateter çaplarının gruplara göre dağııımı, gruplara göre operasyonun hangi damardan yapıldığı, cinsiyete göre dağılımı ve oluşan komplikasyonlar karşılaştırıldı.

Bulgular: Çalışmamızda SVK (Santral Venöz Katater)'ler için kullanılan kateterlerin kalınlıklarının dağılımı gruplara göre farkııık göstermedi. Gruplarda cinsiyet dağılımı açısından bir değişiklik olmadı. SVK USG yöntemiyle 1 hastaya yapılamadı. USG yöntemiyle IJV (Internal Juguler Ven) kateterizasyonunda 1 çoklu işlem denendi ve bu yöntem ile başka komplikasyon yaşanmadı.

Sonuç: USG yöntemi, SVK (SKV (subklavyen ven dışında)) uygulaması için YBÜ'de güvenilir, pratik ve uygulanabilir bir yöntemdir.

Anahtar Sözcükler: Santral venöz kateterizasyon, Landmark yöntemi, Ultrasonografi
Sorumlu Yazar I

Corresponding Author

Dr. Hakan AKELMA

Health Sciences University

Gazi Yaşargil Education and Research Hospital

Department of Anesthesiology and

Reanimation,

Diyarbakır / Turkey

Tel: +90 5052710568

E-mail: hakanakelma@hotmail.com

Geliş tarihi / Received: 13/05/2019

Kabul tarihi / Accepted: 01/08/2019

DOI: 10.35440/hutfd. 563860 


\section{Introduction}

Central venous catheterization (CVC) is an operation used quite frequently in intensive care units for hemodynamic monitorization, parenteral feeding, drug administration and fluid resuscitation and blood sampling (1-6). CVCs can be performed using different methods. However, it is necessary to be careful during application because of serious complications that may occur.

The goal of the traditional anatomic Landmark method is for a guide wire to be passed through after the haematosis of venous blood from the vein by means of needle, for the needle to be removed, and for the catheter to be placed within the vein with the Seldinger technique over the guide wire (7).

Ultrasonography (USG) can be used statically or dynamically in catheterization. When static USG is used, the targeted vein appears on the USG monitor and is highlighted for the skin puncture point. Catheterization can be done blindly just like in the Landmark method. When dynamic USG is used, all procedures (from skin puncture to guide wire placement) are performed together with USG (8). USG makes it possible to image in real time the anatomic relationship of the surrounding structures and operation needle with the imaging of the targeted venous vein. Permission was given to the deviation of anatomic variations like vein and artery transposition and overlapping. The use of USG provides for the visualization, especially in patients with difficult anatomical characteristics (patients with morbid obesity, cachexia, scars in the skin at the puncture locations) of whether there is the correct location, dimension, and thrombosis of the vein. Thus, this application allows us to choose the best skin puncture location.

The purpose of this study is to compare the distributions of the CVCs applied accompanied with a USG or the traditional anatomical Landmark method according to gender, reason for placement, diameter of catheter, and opened vein, and to analyze whether the complications that arise during and after the operation vary in the accompaniment of a USG or the Landmark method.

\section{Methods}

This study was conducted retrospectively, having received ethics committee approval number 39 on 02.03 .2018 from the ethics committee of our hospital, by scanning the files of 100 patients for whom central venous catheters have been placed with the traditional anatomical landmark method accompanied by an ultrasound by a senior assistant (with at least 2 years of experience) or an anesthesiology and Reanimation expert in the adult general intensive care unit between the dates of January 1, 2016 and January 1, 2017. The patients were divided into two groups, the USG group ( $n=41)$ and the Landmark group $(n=59)$. The age, weight, height, body mass index (BMI, we calculated this based on weight and height values), and placed CVC diameters were obtained from the files. Records were also taken for both groups about whether complications developed, the type of complication (local hematoma, pneumothorax, hemothorax, arterial puncture, arterial dilation, arrhythmia, cardiac tamponade), the success in the placement of the guide, the noted number of operations, whether another point was operated from, whether there was malposition in the taken chest $\mathrm{x}$-ray (data was attained by analyzing the digital radiography images captured at the end of the procedure.

Procedures applied to the femoral vein (FV), subclavian vein (SCV), and internal jugular vein (IJV) were recorded. For successful vein enterance, the condition is sought out for the entrance of the entry needle into the vein on the first try percutaneously and for comfortable venous blood aspiration to have been performed.

\section{Operation methods used Landmark method}

For the Landmark method, the catheterization location is chosen by the doctor applying the procedure based on the characteristics of the patient, anatomical location marking, catheterization indication, and experiences of the practitioner. The veins first preferred for CVCs with the Landmark method at our institution are SCVs and IJVs. FV is the second choice.

For IJV and SCV catheterization, patients are brought to a 15-degree Trendelenburg position; and for FV catheterization, patients are brought to a supine position. The fringe area was covered with a sterile covering after being disinfected with $2 \%$ chlorhexidine or $1 \%$ betadine solution; and after the catherization needle, being added to the syringe, was inserted slowly into the target vein with constant aspiration applied with a syringe piston by drawing the $2 \mathrm{ml} \mathrm{Se}$ rum physiological solution into a $5 \mathrm{ml}$ syringe, the guide wire was threaded through the needle after the syringe filled with venous blood; and the procedure continued according to the Seldinger Technique (7).

The anatomic points for IJV catheterization are the medial nerve of the sternocleidomastoid muscle and the pulsation of the carotid artery. (10) For SCV catheterization, it is catheterized 1 centimeter underneath the intersection of $2 / 3$ of the medial and lateral of the clavicle bone and is catheterized in 2 centimeters of the femoral vein inguinal ligament and in 1 centimeter of the palpable pulsations of the femoral artery.

\section{USG method}

For IJV catheterization, the USG (General Electric e-Logic and 1 linear transducer 5 up to $10 \mathrm{MHz}$ are used) probe is placed on the face side of the neck (Figure 1a, b), and for FV catheterization, it is placed $2 \mathrm{~cm}$ underneath the inguinal ligament on the anterolateral side of the inguinal region. When a non-collapsed vein (thrombosis) or vein diameter 
of less than $0.5 \mathrm{~cm}$ is observed, the application is performed on the same vein on the opposite side or on another central vein. The patient preparation and preparing the patients in the Landmark group are the same. The sterility of the USG probe is provided with the placement of the probe in its case after the inside of the endoscopy case is gelled. The image of the targeted vein and needle with USG are provided in figure 1, figure 2, and figure 3 . The USG probe and needle were placed in the form of the out-plane. With this approach, while the needle is seen as a hyperechoic point on the USG, the venous and arterial veins are seen as hypoechoic ovals and circular structures that have welldefined borders. After the vein is taken to the center of the screen with a light movement, the needle is carefully pushed through under the real-time image in the USG until it pierces the anterior wall of the vein and until the blood aspirates into the syringe. After the flow of venous blood appears, catheterization was performed using the Seldinger technique (7).

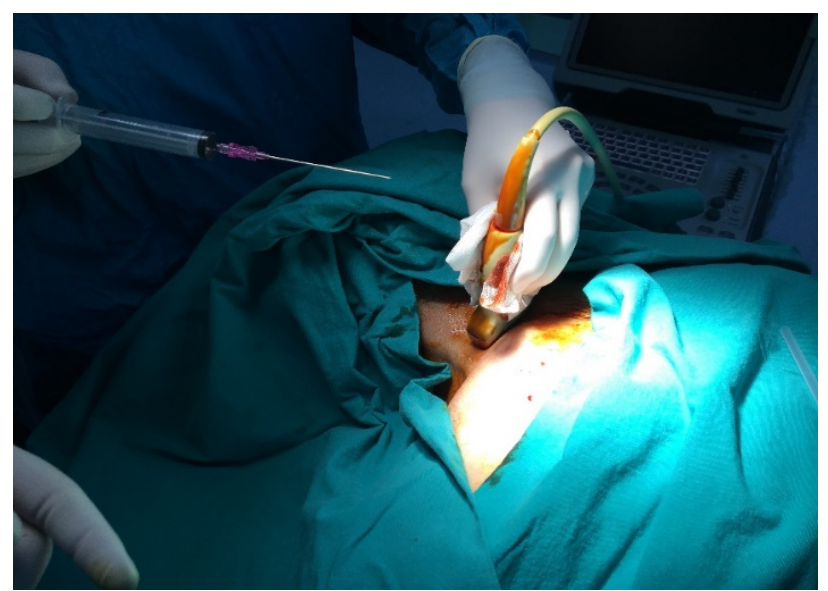

Figure 1. The position of the probe during catheterization of the IJV together with USG (out-plane)

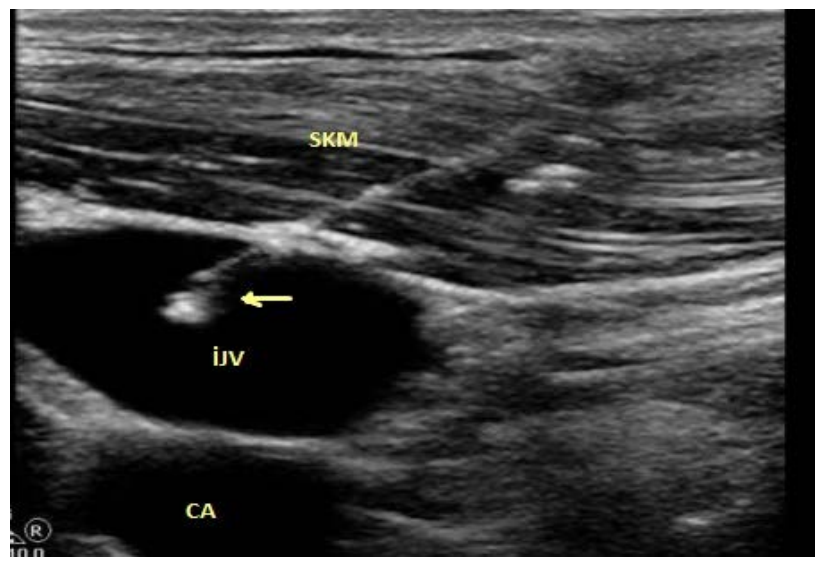

Figure 2. The out-plane appearance of the IJV and needle; Arrow: USG shows the needle that appears as a hyperechoic point in the IJV lumen.

SCM: sternocleidomastoid muscle IJV: Internal Jugular Vein CA: carotid artery

\section{Statistical Analysis}

The SPSS 15.0 program package for Windows was used in the statistical analyses. Normally consistent data were reported as average \pm standard deviation, and categoric data were reported as a percentage (\%). Normally consistent data are evaluated with the Student-t test, and categorical data are evaluated with the Chi-square and Fisher exact tests. For all data, $p<0.05$ was accepted as statistically significant.

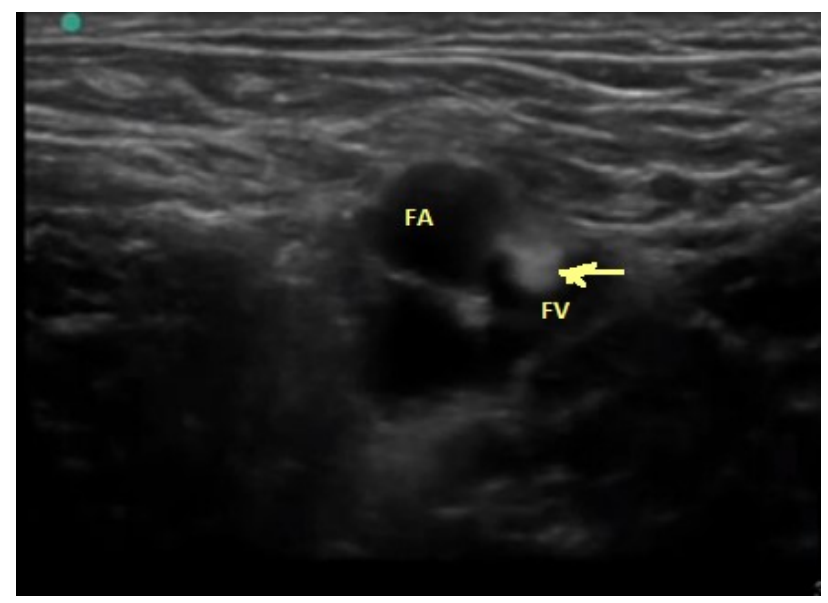

Figure 3. The out-plane image of the FV and needle Arrow: The USG within the FV shows the needle that appears as a hyperechoic point

FA: Femoral Artery FV: Femoral Vein

\section{Results}

Of the patients, 59 were male, and 41 were female. Table 1 provides the average age, average BMl, and day the CVC was opened. There was a statistically significant difference between the 2 groups for age, and age was higher in the Landmark group. There were statistically significant differences in terms of BMI and CVC opening day $(P<0.05)$.

CVC was placed with the Landmark method for 59 of 100 patients and with the USG method for 41 of 100 patients. There were no statistically significant differences between the two catheter dimensions in each group in terms of the dimensions of the placed catheters (Table 2).

When the distribution between genders of the CVCs placed for both groups are looked at, despite there being no statistically significant variation in the Landmark method, there was statistically significant variation in terms of gender distribution in the USG method, and the male gender was at a greater number (Table 3 ).

When we looked at the opening place for CVCs, we saw that there were a total of $87 \mathrm{IJVS}$, consisting of 48 landmarks and 39 USG methods. We saw that 11 of the remaining 13 were opened from the SCV with the Landmark method, and the other 2 were from the FV with the USG method. There were no FV catheterizations that were fitted 
with the Landmark method. There were no SCV catheterizations fitted with the USG method. IJV was the first choice in both methods (Table 4).

Table 1. Comparison in the USG and Landmark groups of Age, CVC placement day, and BMI Index values (Average \pm SD) $(\mathrm{P} \leq 0.05)$

\begin{tabular}{|c|c|c|c|}
\hline & \\
\hline & USG & LANDMARK & \\
\hline METHOD & Average $\pm \mathrm{SD}$ & Average $\pm \mathrm{SD}$ & $P$ Value \\
\hline AGE (Years) & $59.36 \pm 23.17$ & $71.86 \pm 17.41$ & ${ }^{*} 0.003$ \\
\hline BMI(Body Mass Index) & $28.00 \pm 3.59$ & $24.85 \pm 4.50$ & $* 0.000$ \\
\hline Day the CVC was opened (Day) & $4.92 \pm 7.99$ & $12.18 \pm 19.60$ & *0.027 \\
\hline
\end{tabular}

Table 2. Distribution by groups of the thicknesses of the catheter (n\%)

\begin{tabular}{lcccc}
\hline METHOD & Catheter thickness (F) & TOTAL & P value \\
\hline & \multicolumn{3}{c}{ n\% } \\
\cline { 2 - 3 } & $7 \mathrm{~F} \mathrm{n} \%$ & $11.5 \mathrm{~F} \mathrm{n} \%$ & \\
\cline { 2 - 3 } LANDMARK & $49 \% 83.1$ & $10 \% 16.9$ & $59 \% 100$ & \\
USG* & $33 \% 80.5$ & $8 \% 19.5$ & $41 \% 100$ & 0.471 \\
TOTAL & $82 \% 82.0$ & $18 \% 18.0$ & $100 \% 100$ & \\
\hline
\end{tabular}

USG: Ultrasonography

Table 3. Comparison of genders based on groups $(n \%)(P \geq 0.05)$

\begin{tabular}{|c|c|c|c|c|}
\hline METHOD & \multicolumn{2}{|c|}{ GENDER } & TOTAL & $P$ value \\
\hline & FEMALE n\% & MALE n\% & $\mathrm{n} \%$ & \\
\hline LAINDIVIARK & $28(\% 47.5)$ & $31(\% 52.5)$ & $59(\% 100)$ & 0.085 \\
\hline USG & $13(\% 31.7)$ & $28(\% 68.3)$ & $41(\% 100)$ & \\
\hline TOTAL & 41 & 59 & 100 & \\
\hline
\end{tabular}

USG: Ultrasonography

IJV catheterization was applied at a rate of $95.1 \%$ (39 patients) in the USG group, and SCV catheterization and FV catheterization were applied at a rate of $0 \%$ and $4.9 \%$ (2 patients) respectively. While the most frequently operated vein in the Landmark group was the IJV with 81.4\% (48 patients), the second was the SCV with 18.6\% (11 patients), and FV catheterization was $0 \%$. Catheterization was performed with the Landmark method from the left IJV for two patients. It was specified that the reason for this was there was a multiple operation, more than 3 times. Catheterization was conducted in a patient from the left SCV, and the reason for doing this was indicated as stenosis related to previous use of the right SCV. When the technical success for CVCs are examined, the rate of success is found to be $100 \%$ in the USG method while only $79 \%$ of total operations in the Landmark method. There was a statistically significant difference between the two groups in terms of rate of success $(P<0.05)$. In the Landmark method, venous entrance was made on the first try at a rate of $83.1 \%$ (49 patients) for SCV and IJV.At a rate of $16.9 \%$ (10 patients), the veins were able to be entered in more than one operation. There was a statistically significant difference in terms of average number of operations between the groups $(p=0.020)$.

Table 4. Central veins in which the procedure was performed based on groups $(\mathrm{n} \%)$

\begin{tabular}{|c|c|c|c|c|c|}
\hline \multirow[t]{2}{*}{$\begin{array}{l}\text { The vein to which the CVC was } \\
\text { fitted }\end{array}$} & \multicolumn{2}{|c|}{$\begin{array}{l}\text { LANDMARK } \\
\text { METHOD }\end{array}$} & \multicolumn{2}{|c|}{ USG METHOD } & \multirow{2}{*}{$\begin{array}{c}P \\
\text { value }\end{array}$} \\
\hline & $\mathrm{n}$ & (\%) & $\mathrm{n}$ & (\%) & \\
\hline IJV & 48 & $\begin{array}{c}\% 81 . \\
4\end{array}$ & 39 & $\begin{array}{c}\% 95 . \\
1\end{array}$ & ${ }^{*} 0.039$ \\
\hline SCV & 11 & $\begin{array}{c}\% 18 . \\
6\end{array}$ & 0 & $0 \%$ & ${ }^{*} 0.002$ \\
\hline FV & 0 & $0 \%$ & 2 & $\% 4.9$ & 0.166 \\
\hline TOTAL & 59 & $\begin{array}{c}100 \\
\%\end{array}$ & 41 & $\begin{array}{c}100 \\
\%\end{array}$ & \\
\hline
\end{tabular}

When we compared the groups in terms of complications, we saw that apart from Multiple Operation (more than 3 times) being done on 1 patient in the USG method, no complications were experienced. Instead, we saw that the inability to place the guide in 5 of the patients, arterial puncture in 9 patients, local hematoma in 3 patients, and arrhythmia reaching levels of ventricular tachycardia in 7 patients took place in the Landmark Method. During the processes of CVC placed patients, we saw that another operation place was tried 7 times and multiple operations (more than 3) were done 11 times and that 42 CVC placements were made with complications. When the groups are evaluated in terms of total complications, it is seen that there are statistically significant differences between the two groups (Table 5).

\section{Discussion}

Our purpose in this study was to compare the rates of success during CVC with the USG and Landmark methods and the complications that arose. There were statistically significant differences in terms of the average operation number and complications that arose between the groups in our study. We arrived at findings with these conclusions that the CVC implemented with the USG method was more successful than the anatomic Landmark method (Table 5). CVCs can be used for the purpose of managing diagnoses and treatments of the patients in the intensive care unit (ICU). According to a study in Europe of the prevalence of infection in ICUs, $78 \%$ of patients have a CVC (11). CVCs are placed for the purpose of applying fluids and medication, hemodialysis, and hemodynamic monitorization (12). While CVCs have traditionally been done with the anatomic 
Landmark method, operations with USG guidance has begun to gain importance. It has been statistically shown in other studies that the IJV puncture is conducted more safely and successfully with the USG $(13,14)$.

Each region chosen for a CVC has advantages and disadvantages specific to itself. While the risk of infection and thrombosis in long-term use of SCV and IJV is lower, they are safer in terms of the mechanic complications of FV (arterial puncture, local hematoma, vein nerve packet injury, etc.). However, they are the riskiest in terms of FV infection. The bleeding control for the SCV were also stronger for anatomic reasons $(15,10)$. Along with the factors relating to the patient in the selection of the CVC field in many centers, it was reported that the experience of the person performing the operation was influential $(6,18-19)$. IJV catheterization (95.1\%) was conducted more frequently in both groups because our IJV catheterization experiments were greater at our hospital's adult ICU (Table 4).

In many studies conducted on adults and children, CVC placement accompanied by USG increased the success rates and decreased the rates of complications compared with the traditional anatomical Landmark method. External points that are visible and perceivable with a known relationship with the target veins are used to specify the puncture region in the skin as the traditional anatomical Landmark method (10). This method is related to the complications concluding with increasing morbidity, longer hospital stays, increased expenses, and mortality (19). Nine percent of the patients had central venous anatomy, which makes central venous catheterization difficult and increa- ses the risk of failure and complications (11). The percentage of failure in the Landmark method could be as high as $35 \%$ (20). The complications are early and mostly mechanic or late infective and thrombotic that generally emerge during catheterization. The frequency of mechanical complications varies between $5 \%$ and $19 \%$ [21]. While arterial puncture is the most frequently seen complication during the IJV and FV catheterization, pneumothorax is the most frequently seen complication during SCV catheterization (19). No pneumothorax was seen in our study in any of the 11 SCV catheterizations conducted with the Landmark method. Eight arterial punctures $(p=0.007)$ developed during the IJV catheterization conducted with the Landmark method, and no arterial puncture was encountered during the FV catheterization (Table 5).

Direct USG use for CVC provides for the direct imaging of the targeted veins and surrounding structures before and during catheterization. Studies show increased success and decreasing complications in the direct use of USG (12, 22). It is reported in some studies that 2-dimensional USG provided the advantage of security and quality with a lower percentage of arterial puncture and hematoma in the CVC and a higher percentage of success at first operation in the FV (9). In the results of our study, no complication developed, other than a multiple operation (more than 3 times) complication in 1 patient, in the 41 patients in the USG method. We also saw in the patients in the ICU that, when the two-dimensional USG method is compared with the Landmark method, the USG method is superior for CVCs.

Table 5. The comparison of the distribution of the complications during CVC operation in the groups (n)

\begin{tabular}{|c|c|c|c|c|c|c|c|c|}
\hline COMPLICATIONS & USG & LANDMARK & USG & LANDMARK & USG & LANDMARK & TOTAL & $\mathbf{P}$ \\
\hline & \multicolumn{2}{|c|}{ Subclavian } & \multicolumn{2}{|c|}{ Internal Jugular } & \multicolumn{2}{|c|}{ Femoral } & & \\
\hline Is there Malposition in the Lung X-Ray? & 0 & 0 & 0 & 0 & 0 & 0 & 0 & - \\
\hline Guide Was Unable to be Place & 0 & 0 & 0 & 5 & 0 & 0 & 5 & 0.066 \\
\hline Arterial Puncture & 0 & 1 & 0 & 8 & 0 & 0 & 9 & $\star 0.007$ \\
\hline Pneumothorax & 0 & 0 & 0 & 0 & 0 & 0 & 0 & - \\
\hline Hemothorax & 0 & 0 & 0 & 0 & 0 & 0 & 0 & - \\
\hline Cardiac Tamponat & 0 & 0 & 0 & 0 & 0 & 0 & 0 & - \\
\hline Arrhythmia & 0 & 2 & 0 & 5 & 0 & 0 & 7 & $\star 0.021$ \\
\hline Multiple Operation (more than 3) & 0 & 2 & 1 & 8 & 0 & 0 & 11 & $* 0.020$ \\
\hline Were Operations Made from Other Operation Points? & 0 & 5 & 0 & 0 & 0 & 2 & 7 & $\star 0.021$ \\
\hline Local Hematoma & 0 & 2 & 0 & 1 & 0 & 0 & 3 & $* 0.201$ \\
\hline Arterial Dilation & 0 & 0 & 0 & 0 & 0 & 0 & 0 & - \\
\hline Operation Conclusion & 0 & 0 & 0 & 0 & 0 & 0 & 0 & - \\
\hline Was it placed without complications? & 0 & 12 & 1 & 27 & 0 & 2 & 42 & $\star 0.006$ \\
\hline
\end{tabular}

*Statistically significant, USG: Ultrasonography 
The general success rate with the Landmark method is $90.5 \%$, and this is consistent with the other reports where its success rate varies between $85 \%$ and $100 \%(20,12$, $22,23)$. Catheterization is successfully ensured in the first operation for $79 \%$ of patients in our study. When the Landmark method is compared to the USG method, it is seen in light of the literature that the rate of failure is greater.

In the study we conducted, while the incidence of arterial puncture was $15.25 \%$ ( $p=0.0007$ ) with the Landmark method, the formation of local hematoma was $5.08 \%$ $(p=0.201)$ and the incidence of pneumothorax was $0 \%$. (Table 5). The incidence of these complications in the literature varies between $10 \%$ and $13 \%$ for arterial puncture $(12,24,25), 4 \%$ and $8.4 \%$ for local hematoma formation $(17,21)$, and $1 \%$ and $6 \%$ for pneumothorax (26-28). The results of our study are consistent with the literature.

In the study conducted by Karakitsos et al. (14) with regard to complications, in response to the $1.1 \%$ rate of arterial puncture, $0.4 \%$ rate of hematoma, and $0 \%$ rate of pneumothorax with the USG method, these rates were reported to be $10.6 \%, 8.4 \%$, and $2.4 \%$ respectively.

In our study, a significant relationship ( $\mathrm{P}=0.0006)$ was determined between the developed mechanical complications and the catheterization region. In the Landmark method, while 27 of the complications occurred in IJV catheterization, 12 took place in SCV catheterization, and 2 took place in FV catheterization, 1 complication (multiple operation) took place in the USG method during IJV catheterization.

Karakitsos et al. (17) report 100\% success rate with the USG method and $94.5 \%$ success rate with the Landmark method. In the study that Fragou et al. (15) conducted, the rate of success in the Landmark group was $87.5 \%$ while the rate of success was 100\% in the USG group. In the study by Prabhu et al. [19], the USG group had a success rate of $98.2 \%$ compared with the $89.1 \%$ rate of success in the Landmark group. Our study found a success rate of $79 \%$ for the Landmark method against the rate of success of the USG method.

In our study, the USG use resulted in higher general success, greater success on the first try, shorter average duration in the haematosis, lower average number of operations, and lower percentage of mechanical complications (arterial puncture, pneumothorax, and local hematoma). These conclusions are supported in the other literature regarding the effects of dynamic USG over CVCs $(12,22,31$ 33). Only one of the 41 procedures conducted with the USG in our study was a multiple operation, but this didn't lead to any kind of complication.

In our study, $95.1 \%$ of the CVCs and $4.9 \%$ of the IJVs were applied on the FV together with USG. In order to prevent the necessity for more than 1 puncture, caused by mechanical complications and venous anatomical variations like arterial puncture, it is recommended that operations in elective cases can be performed in accompaniment with USG. However, it was reported that ultrasonography wouldn't have any benefit because of clavicle obstruction for $\operatorname{SCV}(29,30)$. Because the physicians at our clinic have no experience of catheterization in USG accompanying $\mathrm{SCV}$, no SCV catheterization has been conducted with this method.

Thrombosis was not observed in any of our patients, and routine heparinization is not implemented within catheters in our unit. In the guide that the CDC (Centers for Disease Control and Prevention) published in 2011, applying routine anticoagulants was not recommended (34).

In our study, we acknowledged that experts and assistants with at least 2 years of experience had a similar experience in the USG applications that they conducted and thus we minimized the effect of the experiment in the rate of success and complication during this process. The out-plane approach was used in all CVC applications in the USG method. During this approach, the tip of the needle may not always be seen, and therefore there is a greater risk of deeper structures being damaged. No complications such as pneumothorax or hemothorax were seen in any of our patients.

\section{Conclusion}

In our study, the distribution of the thickness of the catheters used for CVCs did not vary by group, there was no variation in terms of gender distribution in the groups, the SKV was not entered with the USG method, 1 multiple-operation was tried in the IJV operation with the USG method, and no other complications were experienced. These results make us think that the USG method is a reliable, practical, and applicable method for ICU and CVC (except for SCV) application.

Limitation: Our study being retrospective, the sample size being calculated and Power analysis not having been conducted, the age of the groups, and the statistically significant differentiation of BMI and the catheter fitting day are indicators that the formed groups are not homogenous. The aftermath of the catheters, when it was removed, and whether a catheter infection developed were examined. These situations are restrictive for our article. Conducting randomized, prospective studies in the future will help attain more reliable results.

\section{References}

1. De Jonge RC, Polderman $\mathrm{KH}, \mathrm{Gemke} \mathrm{RJ}$. Central venous catheter use in the pediatric patient mechanical and infectious complications. Pediatr Crit Care Med. 2005;6:329- 39.

2. Schexnayder SM, Storm EA, Stroud MH, Moss MM, Ross AS, et al. Pediatric Vascular Access and Centeses. In. Fuhrman BP, Zimmerman JJ (eds). Pediatric Critical Care. 4th ed. Philadelphia: Elsevier.2011;139-63.

3. Moss M. Central venous catheter complications. Making headway. Pediatr Crit Care Med. 2012;13:694-5.

4. Isgüder R, Gülfidan G, Agın H, Devrim İ, Kararslan U, et al. Central Venous Catheretization in Pediatric Intensive Care Unit: a 
four-years experience. Turk J Ped Em Int Care Med. 2014;1:3138.

5. Anıl AB, Anıl M, Kanar B, Yavaşcan Ö, Bal A, et al. The evaluation of central venous catheterization complications in a pediatric intensive care unit. Turk Arch Ped. 2011;46:215-9. (Abstract in English, Article in Turkish)

6. Akyıldız B, Kondolot M, Akçakuş M, Poyrazoğlu H, Tunç A, ve ark. Çocuk yoğun bakım ünitesinde santral venöz kateterizasyon uygulanan hastalarımızın değerlendirilmesi: iki yıllık deneyimlerimiz. Turkish Pediatric Journal. 2009;52:63-67.

7. Seldinger I. Catheter replacement of the needle in percutaneous arteriography: a new technique. Acta Radiologica. 1953 May 1; 39(5):368-376.

8. Troianos CA, Hartman GS, Glas KE, Skubas NJ, Eberhardt RT, Walker JD, et al. Guidelines for performing ultrasound guided vascular cannulation: recommendations of the American Society of Echocardiography and the Society of Cardiovascular Anesthesiologists. Journal of the American Society of Echocardiography. 2011; 24(12):1291-1318.

9. Brass P, Hellmich, Kolodziej L, Schick G, Smith F. Ultrasound guidance versus anatomical landmarks for subclavian or femoral vein catheterization. Cochrane Database Syst Rev. 2015;(1).

10. Bannon MP, Heller F, Rivera M. Anatomic considerations for central venous cannulation. Risk Manag Healthc Policy. 2011;4:2739.

11. Vincent JL, Bihari J, Suter M, Bruining A, White J, Nicolas-Chanoin $\mathrm{MH}$, et al. The prevalence of nosocomial infection in intensive care units in Europe: results of the European Prevalence of Infection in Intensive Care (EPIC) Study. Jama. 1995;274(8):639-644.

12. Karakitsos D, Nikolaos L, De Groot E, Patrinakos AP, Gregorios $\mathrm{K}$, John $\mathrm{P}$, et al. Real-time ultrasound-guided catheterisation of the internal jugular vein: a prospective comparison with the landmark technique in critical care patients. Critical Care. 2006; 17;10(6):R162.

13. Denys Bg, Uretsky BF, Reddy PS. Ultrasound-assisted cannulation of the internal jugular vein. A prospective comparison to the external landmark-guided technique. Circulation 1993;87:155762.

14. Troianos C, Kuwik R, Pasqual J, $\lim A$, odasso D. Internal jugular vein and carotid artery anatomic relation as determined by ultrasonography. Anesthesiology 1996;85:43-8.

15. Ge X, Cavallazzi R, Li C, Pan SM, Wang YW, Wang FL. Central venous access sites for the prevention of venous thrombosis, stenosis and infection. Cochrane Database Syst Rev. 2012,14;3:CD004084.

16. LeMaster $\mathrm{CH}$, Schuur JD, Pandya D, Pallin DJ, Silvia J, Yokoe D, Agrawal A, Hou PC. Infection and natural history of emergency department-placed central venous catheters. Ann Emerg Med. 2010;56:492-7.

17. Memon JI, Rehmani RS, Venter JL, Alaithan A, Ahsan I, Khan S. Central venous catheter practice in an adult intensive care setting in the eastern province of Saudi Arabia. Saudi Med J. 2010:31:803-7.

18. Paoletti F, Ripani U, Antonelli M, Nicoletta G. Central venous catheters. Observations on the implantation technique and its complications. Minerva Anestesiol. 2005; 71:555-60

19. McGee DC, Gould MK. Preventing complications of central venous catheterization. New England Journal of Medicine. 2003; 348(12):1123-1133.

20. Sznajder JL, Zveibil FR, Bitterman $H$, Weiner $P$, Bursztein SI. Central vein catheterization: failure and complication rates by 3 percutaneous approaches. Archives of Internal Medicine. 1986; 146(2):259-261.

21. Merrer J, De Jonghe B, Golliot F, Lefrant JY, Raffy B, Barre, et al. Complications of femoral and subclavian venous catheterization in critically ill patients: a randomized controlled trial. Jama.
2001; 286(6):700-707.

22. Prabhu V, Juneja, Palepu GB, Sathyanarayanan M, Subhramanyam , Gandhe S. Ultrasound-guided femoral dialysis access placement: a single-center randomized trial. Clinical Journal of the American Society of Nephrology. 2010; 5(2):235-239.

23. Lefrant JY, Muller L, De La Coussaye JE, Prudhomme M, Ripart $\mathrm{J}$, Gouzes $\mathrm{C}$, et al. Risk factors of failure and immediate complication of subclavian vein catheterization in critically ill patients. Intensive care medicine. 2002;28(8):1036-1041.

24. Matthew MJ, Husain FA, Piesman M, Mullenix PS, Steele SR, Andersen $C A$, et al. Is routine ultrasound guidance for central line placement beneficial? A prospective analysis. Current surgery. 2004;61(1):71-74.

25. Mansfild PF, Hohn CD, Fornage DB, Gregurich MA, Ota M. Complications and failures of subclavian-vein catheterization. New England Journal of Medicine. 1994; 331(26):1735-1738.

26. Cronen MC, Cronen PW, Arino P, Ellis K. Delayed pneumothorax after subclavian vein catheterization and positive pressure ventiIation. British journal of anaesthesia. 1991;67(4):480-482.

27. Takeyama $H$, Taniguchi $M$, Sawai $H$, Funahashi H, Akamo $Y$, Suzuki S, et al. Limiting vein puncture to 3 needle passes in subclavian vein catheterization by the infraclavicular approach. Surgery today. 2006;36(9):779-782.

28. Kilbourne MJ, Bochicchio GV, Scalea T, Xiao Y. Avoiding common technical errors in subclavian central venous catheter placement. Journal of the American College of Surgeons. 2009; 208(1):104-109.

29. Breschan C, Platzer M, Likar R. Central venous catheter for newborns, infants and children. Anaesthesist. 2009;58:897-900,9024.

30. Adachi Y, Itagaki T, Suzuki K, Uchisaki S, Kimura K, Obata Y, Doi $M$, Sato S Masui. Multiple difficulties for central venous access required the distal femoral vein catheterization: a case report. 2009;58:913-6.

31. Miller AH, Brett RA, Mills TJ, Woody R, Longmoor CE, Foster B. Ultrasound guidance versus the landmark technique for the placement of central venous catheters in the emergency department. Academic Emergency Medicine. 2002;9(8):800-805.

32. Shah A, Smith A, Panchatsharam S. Ultrasound-guided subclavian venous catheterisation-is this the way forward? A narrative review. International journal of clinical practice. 2013; 67(8):726732.

33. Troianos $C A$, Jobes $D R$, Ellison $N$. Ultrasound-guided cannulation of the internal jugular vein. A prospective, randomized study. Anesthesia \& Analgesia. 1991; 72(6):823-826.

34. O'Grady NP, Alexander M, Burns LA, Dellinger EP, Garland J, Heard SO, Lipsett PA, Masur H, Mermel LA, Pearson ML, Raad II, Randolph AG, Rupp ME, Saint S; Healthcare Infection Control Practices Advisory Committee. Guidelines for the prevention of intravascular catheter-related infections. Centers for Disease Control and Prevention. Am J Infect Control 2011;39:1-34. 